\title{
Ecological Studies of Ecosystem Health Indicators at Nayagram of Paschim Medinipur District in Lateritic forests of Southwest Bengal, India
}

\author{
Debabrata Das ${ }^{1}$ and Pampi Ghosh ${ }^{2}$ \\ 1-Angiospermic Taxonomy and Ecology Laboratory, Post Graduate Department of Botany, Darjeeling Govt. \\ College, Darjeeling, West Bengal, India. \\ (Ex-Asst. Prof. of Botany, Jhargram Raj College, Jhargram, Paschim Medinipur, West Bengal and Ex- \\ JRF/SRF-ICFRE Project at CNH, Gope Palace, EX-JRF/SRF-Flora India Project, Central National \\ Herbarium, Botanical Survey of India, Shibpore, Howrah, West Bengal, India \\ 2-Department of Botany, Seva Bharati Mahavidyalaya, Kapgari, Paschim Medinipur, West Bengal, India.Ex- \\ Headmistress, Pasang Girls' High School, Pasang, Debra, Paschim Medinipur)
}

\begin{abstract}
The present article reflects the vegetation structure in diverse eco-habitats along with health indicators to conserve the ecosystem in Nayagram areas of Paschim Medinipur, West Bengal, India. It broadcasts phyto-diversity and dynamics of vegetation which need to study or not in the present day scenario in lateritic forests of Southwest Bengal of West Bengal. The diverse types of natural resources of the said area are going under threat due to illegal felling and unscientific management which continuously causing serious loss of the biodiversity due to loss of resources in the said area. Ultimate goal is destruction of vegetation and habitats which lead to environmental degradation. Example is "critically cited as the wild life and man conflict" in the said area which is going on year after year. The elephant and wild quadrupeds are the vivid examples after the report collected from forest range office this year. So, it needs the conservation following global management along with the management of local people and forest officers in the said area. Our study signifies the probable goal to cope the global degradation of environment and suggestions forwarding to establish a relationship between ethnic, non-ethnic versus plants and wildlife of the said area to justify the questions of problematic kind. It aims to study more regarding soil and water as resource of the said area. Not only the above one it reflects the total economic value and total environmental value (TEV and TEnV) to mitigate the problem in the said area as model study. A total 10 steps for flow chart are incorporated in this paper which may be used to make the environment eco-friendly and solve the problem in near future through holistic approach using pilot plan.
\end{abstract}

Keywords: Ecological indicators as Vegetation, Dynamics, Biodiversity Values, Conservation and management at Nayagram, West Bengal.

\section{Introduction}

The ecological indicators applied today in different contexts, for different ecosystems, and for different problems can be classified on eight levels from the most reductionists to the most holistic indicators. Ecological indicators for ecosystem health assessment (EHA) do not include indicators of the climatic conditions, which in this context are considered entirely natural conditions (Jorgensen et al., 2010). Indicators of ecosystem are of varied kinds started from abiotic components to biotic components of the environment i.e. within lithosphere, atmosphere as well as in hydrosphere. Many organisms grow there and take nutrients for the development and suit there better in passing time. So, nutrients uptake and flow of the nutrients from one state to another is going on from tiny micro organisms to a multi-cellular big animals and in case of big plants. But, as a whole the type and pattern of uptake of nutrients and flow of energy from one state to another in the said environment is different. Problem is that, men are the culprits in the environment and changing the environment by doing natural activities, losses vegetation, wildlife and soils, including degradation of different kinds at different levels by varied means. As a whole, the day to day activity of increasing population causing nuisance and change the environment even depleting the resource and contaminate the resource which lead to change the said environment more adverse than the previous one. So, restoration ecology starts the action to stabilize the ecosystem to its pristine. Loss of vegetation, loss of soil, loss of micro as well as macro flora and fauna is a common episode of the today's' theme. So, to know the actual strategy needed as holistic approach which is to be required to know the status of ecosystem in the environment i.e. either the ecosystem is fit with the perspectives of modern environment or not. i.e. about ecosystem health. Therefore, monitoring of soil status, microbial status, lower and higher plant community and nutrients including status of wild life is urgently needed. So, the departments of Government and semi Government including NGOs are started action to know 
the actual status of ecosystem health and strategy development is being developed to establish a link between the present and past scenario of the ecosystem after proper study and monitoring. The continuous study will thus generate a scale to measure the level of health status of Ecosystem and control the deviation towards abnormality of the vegetation soil and wildlife as a whole in an area. Thus, it can causing the next stage work as eco restoration which will work automatically by the civilized persons of the society to earn good and dynamic strategies to monitor the quality environment with the help of indicators. Theses may be the soil quality, water quality, quality of vegetation of varied kinds, people and wildlife including different resources.

Vegetation is a complex structure of floral elements under specific microclimatic conditions over the globe. In Oxford Dictionary, modern meaning of vegetation is therefore, 'Plants considered collectively especially those found in a particular area or habitat'. But, recently some authors found that the meaning is contradictory because it may be past or present record of plants or their parts remaining in the geological past or in the form of vivid perusal condition (Bertini and Maritinetto, 2008, 2011). The present study therefore aims to focus following mixed mesophytic types in forests and neighboring areas which pursue of recent trends of composition.

Furthermore, it includes the composite growth and development of green belt in a habitat with particular circumscription and selected composition. It may vary from site to site even from place to place due to fluctuation of ecological factors as the episode of the population in every moment at every corner. Say for example, one micro site during monsoon filled by herbs, shrubs, trees and parasites of varied kinds but during winter most of the elements become vanish due to unfavorable conditions. During summer a few of them are present due to the acclimatization in the said habitat. The dominancy is found in case of trees rather than shrubs and followed by herbs. Perennating propagules always present in the same habitat due to reach the ultimate goal i.e to revive the same species during favorable conditions i.e. in monsoon. This phenomenon is common everywhere which face a serious problem, if you change the condition of the microclimate due to induction of fire or loss of the habitat by any artificial means. A good example is over logging or soil leaching and soil degradation. Lateritic forests face boththe forest fire as well as soil degradation due to heavy runoff of water and high degree of leaching through rills or gullies in forest areas. In agricultural land and in wasteland this phenomenon is more severe.

The common problems are the problems of the water and soil which are available more in degraded land or plantation sites. Small patches of water bodies are also found in the vicinity of the forest or near the bank of river which face havoc land degradation. Vegetation cover in all the sites including agricultural land protects soil and change the texture and rigidity of the soil and soil becomes more congenial to the plants and become more productive. Apart from the natural forest, plantation stand also support the growth of some natural vegetation and protect soil erosion and transfer the soil more reliable for growth and development of vegetation. The rate and speed of the development of land and soil loss is havoc which may vary from site to site due to flow of water and speed or velocity of the water runoff.

Vegetation is a composition of plant species. So, before going to study the vegetation, taxonomy and species inventory study is essential for any site. Remembering the theme, Dennis and Ruggiero (1996) suggested four possible approaches for orienting an inventory namely-(1) Survey of major elements; (2) Identification of key stone species and indicator elements; (3) Identification of target elements, such as threatened species, and (4) Comprehensive assessment of all other important elements, such as exotic or alien species/invasive species, flagship species, and economically useful taxa. The purpose and orientation of an inventory is always for the raise of data to enrich data bank for proper management of ecosystem and some of the good data over the old one are called indicator data which helps to study the quality health of an ecosystem. The inventory, therefore will determine the choice of material and methods, which on other hand will influence the completeness of the inventory in terms of taxonomy, community, ecosystem dynamics, strategies of development, fluctuation of elements over time and space, geographical space, seasonal variations of the occurrence, temporal representation, stability and functioning etc. (Das, 2014; Solbrig, 1991; Stohlgren and Quin, 1991).

Nayagarm in Paschim Medinipur is a heterogenous dry deciduous sal (Shorea robusta) dominated mixed mesophytic forest (Map 1). The degraded land nearby is characterized by its lateritic PAN form. So, the available plant elements found there are Schleichera oleosa, Terminaliaarjuna, Diospyros melanoxylon, D. tomentosa, D. sylvatica, Madhuca indica, Shorea robusta, Glochidion lanceolarium, Agave sisalana, Bryophylum calycinum, Alangium lamarkiana, Zizyphus jujuba, Z. oenoplea, Bambusa spp., Phoenix acaulis, Morinda tictoria, Meyna laxiflora,Gelonium multiflorum, Streblus asper etc. The introduced type of floral elements found here are Ailanthus excelsa, Anacardium occidentale, Anthocephalus cadamba, Spathodea campanulata, Delonix regia, Peltophorum ferugenium, and Jacaranda mimusifolia, Pongamia pinnata, Glricidia maculate, Disoxylum sp., Millingtonoia hortensis, Markamia sp., Swietenia macrophylla, S. mahagoni etc. In agricultural land people cultivate wheat, rice, sesamum, linum, sugarcane, beet, radish, cabbage, spinach, potato, chilly, rape seed, mustard, beans, peas, grams, cajanus, carrot, turnip, 
beans, tomato, watermelon, cucumis, bitter gourd, summer squash, winter squash, soybean etc. round the year. They use huge quantity of pesticides, insecticides and chemical fertilizers to grow them better in the same land. The leeching materials of chemicals (toxic) run to the water nearby and through the down flow of water ultimately reaches to the sea causing dangerous effects on flora and fauna ultimately to man. River Subarnarekha (flowing from Chotanagpur plateau of Bihar-Jharkhand to West Bengal to Odissa to Bay of Bengal) causing this type of activity by which total surface water becomes polluted not only from Nayagram area but also from large riverbank/ belts throughout the country. People should be more knowledgeable regarding this to check the inflow of dangerous chemicals and scientists should study there to know the actual situation in which these can cut the level of thresholds. Government should plan properly to use the pollutants on these fields to grow plant better following guidelines of spraying pesticides and chemicals over the land. So, good indicators about healthy environments may be the data to monitor the environment a better one, to access the quality of the ecosystem through rigorous study. This means study of soil, chemicals, pesticides on plants and animals, insecticides and their effects on ecosystem, study of behaviors of plants and animals, forests vegetation, vegetation of agricultural kinds, vegetation of natural forests, plantation sites, and on degraded lands. As a whole, need to study and monitoring of the ecosystem and analysis of health of the ecosystem following various guidelines using value prediction through different formulations (Norton, 1987).

The study sites have some pockets here and there in natural forests, degraded lands and in plantation stand which grow a small number of aquatic products which have quality importance. But from botanical point of view this has a vast economic and ecological significance. Therefore, to run the smooth life style and to develop economy of rural people, proper management is required to enhance the sustenance of products as well as economy. So, following points are to be studied in near future and therefore the present study includes-

1. To study the Total Environmental Value to function the primary value and total economic value (UNEP, 1995) in field.

2. To study how the underlying pattern of Ecosystem and flow of nutrients perform their functions in ethnic and non-ethnic area of Nayagram area.

3. To study the types of vegetation, i.e.natural forest, degraded stand, plantation stand and agricultural types, includingthe seasonal flow of crop produced.

4. To study the direct use value (MacArthur, 1997) and the management of resource by the people.

5. Role of forest departments and NGOs to develop sustenance of economy through the study of Consumptive use value (CUV) and Productive use value (PUV) following Ravi and Pushpagadan (1997).

6. Study of illegal collection of plants, and prepare a linear line to understand its impact on vegetation in forest, agricultural land, in degraded land and in plantation stand. As a whole, the pattern of species diversity (Mac Arthur, 1985).

7. To prepare Parallel guideline to grow vegetation better and management of resource with some examples. So, need model study in different parts of the whole area to develop environment as model environment.

8. To study major NTFPs of the said area and identify the nodal markets for the sale of the products without hampering the ecosystem.

9. Productive use value (PUV) study for fruits, seeds, latex, timber, medicinal plants, fibres, flosses, gums, glues, resins, red ants, mushrooms, tasar, lac and others.

10. Quasi-option value (QOV), represents 'the value of the future information made available through the preservation of a resource' also called strictly option oriented one to mitigate the goal. Arrow and Fischer (1974) suggested that is predicted to qualify the first run option value which is 'willingness to pay to safeguard an assets for the option of using it in future' (Mac Arthur, 1974).

\section{Study Area}

The study area is Nayagram Community Development Block (CDB) under Jhargram Sub-division of Paschim Medinipur District of West Bengal, India. The community development block has 503.15 square kilometer area. Head quarter is situated at Baligeria. Gram panchayats of Nayagram Community development block are Arrah, Baligeria, Barakhakri, Baranigui, Berajal, Chandrarekha, Jamirapal, Kharikamathani, Malam and Nayagram (Anonymous, 2011).The main river flowing through this block is Subarnarekha. The area is adjacent to Odissa state of India. 


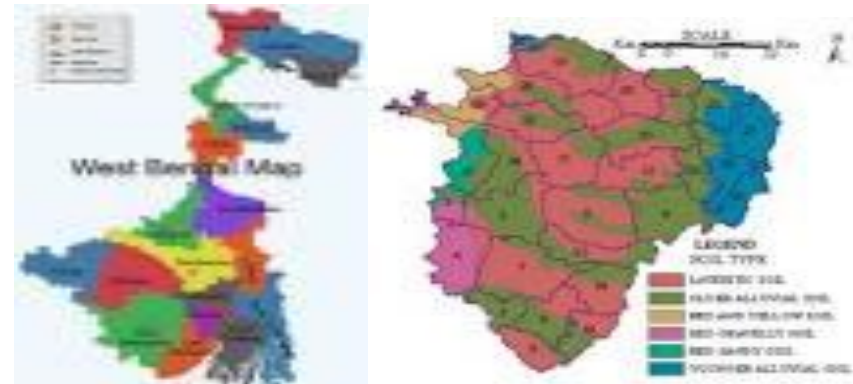

Map 1. West Bengal map (Left) and Map of the Nayagram Community Development Block (Right), courtesy: WWW.mapindia

Climate

The area is dry and soil is red lateritic which falls under Paschim Medinipur District. The maximum temperature recorded in April is 45-46 degree centigrade and minimum temperature is 6 degree centigrade (Sarkhel, 2014). The average annual rainfall is about $1500 \mathrm{~mm}$. Number of rainy days per annum is near about 52 days. Though this year, open temperature rises up to 52 degree centigrade in the month of May due to no action of low depression.

\section{Vegatation}

Here vegetation is dry deciduous sal dominated along with natural forest species like Madhuca indica, Terminalia bellerica, T. chebula, T. catappa, Bombax ceiba, Dalbergia latifolia, D. scandens, Holarrhena antidysenterica (=H. pubescens), Cassia fistula, Anogeissus latifolia, Lagerstroimeia indica, Aegle marmelos, Buchanania lanzan, Semecarpus anacardium, Butea frondosa etc. Woody climbers found here are Combretum decundrum, Hemidesmus indicus, Ichnocarpus pubescens, Moringa pterigosperma, Tinospora cordifolia, Dioscorea bulbifera, Ichnocarpus frutescens, Butea superba, Bauhinia vahlii, Spatholobus roxburghii, Tiliacora racemosa, Aganosma dichotoma, Cephalendra indica, Trichosanthes pametta, Jasminum dispermum, J. sambac, Dalbergia stipulacea, Samania saman, Albizzia lebbeck, Cereus hexagonus, Aristolochia indica, Dalbergia sissoo, Curculigo orchioides, Diospyros tomentosa, D. sylvatica, Clerodendrum indicum, Mangifera indica, Ficus religiosa, F. benghalensis, F. hispida, Gelonium multiflorum, Glochidion lanceolarium, Annona squamosa, A. reticulate, Zizyphus rugosa, Flacourtia ramaontchii, Pterospermum acerifolium, Tectona grandis, Borassus flabellifer, Phoenix sylvestris, Cassia ocidentalis, Calotropis procera, C. gigantean, Leonotis nepetifolia, Martynia annua, Tribulus terrestris, etc. Plantation sites include species like Eucalyptus, Acacia, Anacardium and a lot of Bamboos (Plate-1 to 6).

\section{Ethnic People}

Main composition of the human resource in the said area is filled by tribal people. The communities are Santhals, Mundas, Lodhas, Bhumijs, Oran and Kheria. All the people are forest dependant but some are associated with cultivation though others collect fibers, flosses, medicinal plants from forests and waste lands and fishes from river Subarnarekha nearby.

\section{Medicinal Plants of The Study Area}

The area has good potential of medicinal plants. These are species like Acacia nilotica, Cissus quadrangularis, Pongamia pinnata, Schleichera oleosa, Achyranthes aspera, Acorus calamus, Allium sativum, Andrographis paniculata, Vitex negundo, Tinospora cordifolia, Withania somnifera, Rauvolfia serpentina, Morinda citrifolia, Mimosa pudica, Kalanchoe pinnata, Hemidesmus indicus, Tylophora asthmatica, Gymnema sylvestre, Euphorbia nerifolia, Datura metel, Ocimum basilicum, Calotropis procera, C. gigantean, Azadirachta indica, Barleria prionitis, Amorphophalus margaratiferum, Streblus asper, Alangium salvifolium, Aristolochia indica, Rothia sp., Celtis orientalis, Cissus adnata, Curculigo orchioides, Polygala crotalarioides, Zizyphus jujuba, Z. rugosa, Zornia diphylla, Orthosiphon spp., Adhatoda vasica, Mollugo spergula, Enhydra fluctuens, Wedelia calandulacea, Vernonia anthelmintica, Abelmoschus moschatus, Solanum trilobatum, Dicliptera sp., Ipomoea carnea, I. aquatic, Glenus lotoides, Moringa oleifera, Morinda citrifolia, Agave Americana, Spondias dulcis, Scoparia dulcis, Averhoeea carambolaetc. 


\section{Exotic Species}

The most promising exotic but fuel wood species found here are Lantana camara, Chromolaena odorata, Hyptis suaveolens, etc. which are naturalized in the said area supplies dry biomass for their own purpose or sale elsewhere.

\section{Wildlife}

As the forest is dry deciduous so, number of local kinds of wild animals available less number, maximum are residential from other side as they posses temporal stay. The good example is Elephant migrated from Dalma Range of Jharkhand State. So, as a whole wildlife members are Elephant, Rabbit, Porcupine, Snakes, Lizards, Butterflies, Insects, Ants, Spider, birds of miniature kind, and common birds. Other birds available are kingfisher, Crane, Crow, Raven, Dove, Parrot and Parakeet etc. Pigeon and Drongos are available here in the area where cultivated crops are common.

\section{Man and Elephant Conflict}

It is a common practice in Nayagram Forest of Paschim Medinipur. Not only that, this problem found as common throughout the southwest Bengal. According to forest officer, "Man-Elephant conflict in South West Bengal viz., Purulia, Bankura and West Midnapore, has been a major administrative issue for the West Bengal Forest Dept. The problem started in 1987 when elephant herds from Dalma Wildlife Sanctuary, situated in the State of Jharkhand started migrating to Jhargram Division in the state of West Bengal." stated by Chanda (Web article). This is due to lack of fodder in the habitat particularly in the entire tract of Chotanagpur Plateau including lateritic belt of West Bengal and Jharkhand states.

\section{Materials and Methods}

Extensive field visits were carried out to different places of the study site which falls in between eastern part of Nayagram to western part of Nayagram by pointing some stations. The study sites having different zones, like natural forests, degraded land, plantation stand filled with Eucalyptus and Teak, river banks with Sissoo (Dalbergia sissoo) plantation, highland, banks of ponds, creaks, small canals and low lying land have been taken for consideration to study the quality of the ecosystem. The entire coastal area has low plantation of Eucalyptus and Ailanthus along with some exotic ornamental species. The orchard species likeAnacardium occidentale is also found there in the gardens and boundary areas of self occupiers'land of the forest department.

The sites fall under West Midnapore Forest Division and the range is Nayagram in the state of West Bengal. Association studies of plants have been taken for terrestrial ecosystem though for checklist preparation nearer species was also taken. So, the sites with low fluctuations and high eco-niche have been omitted to avoid the biasness of the data. The quadrats as well as transects were taken for monitoring vegetation in late summer, monsoon and winter also as per the latest ecological methods. For eco-restoration study, vegetation monitoring was done following the concept of Greipsson, 2011. Parameter taken for stability study and concept of structure and function of elements in ecosystem along with dynamics of vegetation idea accepted from Dash and Dash, 2010 was taken. The management of the policymaker and similar managerial was taken from internet to get idea regarding the present day scenario of forest vegetation including soil. Books, Journals and magazine including registers of different departments were also consulted for Literature work. Interviews and cross references were studied using Participatory Rural Appraisal (PRA) technique in field. Plant specimens from field were also collected and processed for presentation as herbarium specimens and for identification using botanical and ecological standard. Specimens were carefully studied, critically examined and cross checked with the specimens housed in the CAL herb, BSI, Shibpore, Howrah. For conformity of specimens, local floras were consulted (Prain, Vol-I-II, 1903; Hains, Vol-I-III, 1921, Hooker, 1892-1897). To consult some publications, Taxonomy and similar research papers from website have been downloaded and followed by Ghosh, 2014; Das and Das, 2014; Ghosh and Das, 2014, Das, 2014b. Some books published by West Bengal Forest Directorate, Research Wing (Anonymous 2005, 2010), BSI, Kolkata (Anonymous 1997) have also been consulted to analyze the report along with our collections that the plants are either medicinal or not. Methodology used for abundance study followed by Groom et al., (2006) along with the thesis of Das (2007). Relevant literature have been collected and consulted for the preparation of the manuscript. The voucher specimens were housed in our custody and after preparation will be deposited in the departmental herbarium.

For the study of vegetation Ecology following methodology was used which is given below:

\section{Selection of Sites}

Sites were selected in four different regions of the Range of Nayagram, Paschim Medinipur at random in West Bengal. Topographically the sites belong to different types i.e. near the alluvial plain, in deep jungle, in disturbed sites and in plantation sites. In each site 10 quadrats laid out randomly to study the vegetation. In total 
40 plots in each site $(1 \mathrm{~m} \mathrm{X} 1 \mathrm{~m}$ plots for herbs) were selected for regular monitoring of status of plants in the said area to study the population dynamics.

\section{2. $\quad$ Periodicity of Field Study}

Study was made in three seasons i.e.summer, monsoon and in winter round the year for analysis of vegetation. In this particular region three seasons namely monsoon (July-October), winter (November-February) and summer (March-June) are well perceived. During study some specimens were collected and Herbarium specimens were prepared as per the methods of Rao and Sharma, 1990.

\section{Ecological Studies}

Vegetation in a community is a dynamic biological system consisting of a number of plant and animal species. Vegetation at a particular site is the result of interaction of various climatic and biotic as well as edaphic or soil factors. During the course of succession, many species compete with each other to establish their hold on the vacant niches. Consequently, some tree species occupy the top position and become dominant in the community and others are either contented with their lower position and show suppressive phyto-sociological status or eliminated from the system. So, as a whole there are some factors that govern the complete process, though in the said habitat elements of flora and fauna of wild kind sit together and also possess their special interactions through co-existence. This natural process continue the process of cyclic rotation of propagules or may change due to change of habitat or governing forces to complete the life cycle and challenge their preposition as presence or absence.

\section{Synthetic Characters}

The vegetation survey was made in the sites selected by laying quadrats at random. Vegetation data of the above mentioned four sites was taken from forests, degraded land, and plantation stand of the area. In open tract of aspect, the vegetation study was made by belt transect on four exposures i.e.in margin, center, and roadside of microhabitats, according to the principles of "landscape" approach followed by Whittaker, 1972. The size of the quadrat was fixed by method of "species area curve" (Oostings, 1956) which was $1 \mathrm{~m} x 1 \mathrm{~m}$ area for the herbaceous vegetation. Area of $5 \mathrm{~m}$ x $5 \mathrm{~m}$ was taken for shrubs and $10 \mathrm{~m} \times 10 \mathrm{~m}$ area was taken for tree species to study the frequency, density and abundance of the species. The numbers of quadrats required were determined by plotting the number of species against the number of quadrats. The analyses of quadrat values were made following Dombois and Ellenberg, 1974.

Plant species encountered in each quadrat was listed and identified on the basis of floristic studies of regional vegetation made by Prain (1903, revised Edn. 1963), Flora of West Bengal made by BSI in a series, Mabberley, 1997and the names were cross- checked with the help of Bennet, 1987.Frequency density and abundance values were calculated for each species. The importance value index (IVI), is an integrated measure of relative frequency, relative density and relative dominance was calculated following Curtis, 1959. The formulae are given below:

Frequency $=$ Total no. of quadrats in which the species occur/Total number of quadratsstudied $\mathrm{x} 100$; Density = Total no. of individuals of a species in the entire sample plots/total no. of sample plots studied. Relative Density $=$ Total number of individuals of a species / Total number of individuals ofall species x 100; Abundance $=$ Total number of individuals of the species in all the quadrats/ Total number of quadrats in which the species occurred.

\section{Diversity Index (H)}

Diversity index $(\mathrm{H})$ of each sample stand was calculated as Shannon and Wiener, 1963. $\quad(\mathrm{H})=-\sum[$ $(\mathrm{ni} / \mathrm{N}) . \operatorname{Ln}(\mathrm{ni} / \mathrm{N})]$, Where ' $\mathrm{ni}$ ' is the IVI of individual species and $\mathrm{N}$ is the total IVI of all the species.

6.

\section{Dominance Index}

Concentration of Dominance $(\mathrm{Cd})$ of each stand was calculated following the formula given below by Simpson, 1949.

$\mathrm{Cd}=(\mathrm{ni} / \mathrm{N})^{2}$

Where 'ni' is the IVI of individual species and ' $N$ ' is the total IVI of all the species.

\section{Evenness Index}

Evenness Index (e) was calculated according to Pielou, 1966.

$\mathrm{e}=\overline{\mathrm{H}} / \log \mathrm{S}$

Where, $\mathrm{H}=$ Shannon index and $\mathrm{S}=$ Number of species. 


\section{8. $\quad$ Species Richness Index}

Species Richness index (d) was calculated according to Margalef, 1958.

$\mathrm{d}=\mathrm{S}-1 / \log \mathrm{N}$.

Where, $\mathrm{S}=$ Number of species, $\mathrm{N}=$ Importance Value and

$\mathrm{d}=$ Species richness.

\section{9. $\quad$ Similarity Index}

To avoid individual variation the degree of similarity is expressed mathematically on the basis of any quantitative character (Number of species in the present case). The indices of similarity of community coefficient (IS) between any two sample sites or communities was made by the formula of Sorensen,1948 as described by Muller-Dombois and Ellenberg, 1974.

IS $=(2 \mathrm{C} / \mathrm{A}+\mathrm{B}) \mathrm{X} 100$

Where, $\mathrm{A}=$ Number of species in one stand / Community, $\mathrm{B}=$ Number of species in another stand / Community and $\mathrm{C}=$ Number of species common to both the communities.

Like the above mentioned indices, other indices were used alternately to study the ecosystem health, because the under mentioned indices are easiest to study the composition of different populations nearby.

10. Sorensen's Coefficient (SC): This method measures similarity between two habitats (Habitat A and Habitat B)

$\mathrm{Sc}=2 \mathrm{a} / 2 \mathrm{a}+\mathrm{b}+\mathrm{c}$

Where $a=$ number of species common to two habitats, $b=$ number of species present in habitat $B$ but absent in habitat $\mathrm{A}, \mathrm{c}=$ number of species present in site $\mathrm{A}$, but absent in site $\mathrm{B}$. The index value varies between 0 to 1 . Zero indicates no similarity and 1 indicates maximum similarity.

11. Bray-Curtis measure (B): This is a measure of dissimilarity; hence 1-B is taken by measure of similarity. The formula suggested by Bray and Curtis, 1957.

$\mathrm{B}=\Sigma\left(X_{i j}-X_{j k}\right) / \Sigma(\mathrm{Xij}+\mathrm{Xjk})$

Where, $\mathrm{Xij}=$ number of individuals of $\mathrm{i}^{\text {th }}$ species in sample or habitat or community $\mathrm{j}, \mathrm{Xjk}=$ number of individuals of $\mathrm{i}^{\text {th }}$ species in sample or habitat or community $\mathrm{k}$.

Morisitta's Index (MI): This index is suggested by Morisitta, 1959 which is calculated as

$\mathrm{MI}=2 \sum\left(X_{i j} X_{j k}\right) /\left[\left(\sum \mathrm{X}^{2} \mathrm{ij} / \mathrm{N}^{2}\right)+\left(\sum \mathrm{X}^{2} \mathrm{ik} / \mathrm{N}^{2} \mathrm{k}\right)\right] \mathrm{NjNk}$

Where, $\mathrm{Xij}=$ Number of individuals of $\mathrm{i}^{\text {th }}$ species in sample or community $\mathrm{j}$.

$\mathrm{Xik}=$ Number of individuals of $\mathrm{i}^{\text {th }}$ species in sample or community $\mathrm{k} . \mathrm{Nj}=$ total number of individuals in $\mathrm{j}$. $\mathrm{Nk}$ $=$ Total number of individuals in $\mathrm{k}$

This index takes values 0 to 1 . Dice (1945) and Wolda (1981) methods may be made to study the same in the same field though the site is heterogeneous with admixed vegetation.

\section{Study of Total Economic Value:}

Total Economic Value (TEV) was calculated from Vegetation using following formula:

$\mathrm{TEV}=\mathrm{DeV}+\mathrm{I} 2 \mathrm{~V}+\mathrm{TrV}$ suggested by Norton (1987).

Where, $\mathrm{DeV}=$ Demand value, $\mathrm{I} 2 \mathrm{~V}=$ Intrinsic value, $\mathrm{TrV}=$ Transformation value.

\section{Total Environmental Value:}

The total Environmental Value was calculated using following formula as suggested by UNEP (1995).

$\mathrm{TEnV}=\mathrm{G}[\mathrm{PV}$ (Non-anthropocentric instrumental value), TEV (Anthropocentric value)].

Where, PV-Primary value, TEV-Total economic value, G-Goods.

\section{Results And Discussion}

The overall study discusses with three heads namely-1) Pattern and diversity of vegetation in Nayagram forest of Paschim Medinipur, 2) Degradation of ecosystem as a whole due to culminating factors with special reference to different eco-geological factors including site factors probably used in forestry. The factors repost the action and counteraction of forest people along with the activity of poachers inside the forest which become loss of resource in several ways, 3) restoration of ecosystem and sharing of knowledge by the people, of the people and for the people throughout the area of Nayagaram.

Diversity value of the vegetation is in between 0.8 to 1 and second one is more or less $80 \%$ similar. So, dissimilarity is 1-80 i.e. $20 \%$. Morisitta's Index (MI) is in case of the same area is near about $80 \%$. The results also coincides the value calculated from Sorensen (1948) as described by Muller-Dombois and Ellenberg (1974). From the results it is observed that the site is more or less natural in comparison to the other parts of the West Bengal having lateritic Sal dominated forest (Das, 2007). 
Degradation of land is slightly influenced by natural processes triggered by manmade cause. This is significant and the nutrient flow during the monsoon is havoc. So, artificial management is urgently required to establish small herbaceous vegetation in degraded land and in plantation sites. Agricultural land is also posses same type of degradation therefore, alternate cropping is to be incorporated in the same area with trial and error basis and need to check the usual spraying of chemical pesticides as well as insecticides. Use of bio-fertilizers and application of organic manure including chemical fertilizers are to be incorporated in a proper way very soon. Soil and water are not fit to the wildlife because surface water bodies are not enough even the habitats are filled with obnoxious weeds depleting the status of the aquatic bodies due to eutrophication. Immediate action should be taken to study the quality of water and to study the $\mathrm{C}: \mathrm{N}$ ratio of the soil. Study of correlation of nutrients and vegetation is required to analyze the actual situation there by.

The first point significant i.e.need to develop methods to study the vegetation in a regular basis to access the pattern and diversity along with the fluctuation of composition round the yearand need framing a guideline to measure the forest as whole to its all round development. Second one is degradation of land and natural resource particularly the green vegetation sustained there or not sound fully suggests that the ecosystem is functioning to flourish the elements of all including flow of nutrients by different activities of the forests, degraded land including agricultural fields to access the system complete. Third one is the last phase study and application oriented approach to research in the same fold to fulfill the goal through large peripheral scale to access the potentialities of public and forest department with the help of students, researchers, workers, social workers, NGOs and local people including Forest Protection Committees (FPCs) to solve the problem and reclaim the same by different ways. It broadcasts, soil, land, people, resource, technology and management to access the complete system more reliable to withstand there. The negative scope of development is not predicted here so, infrastructure and development of skill in the field to develop managerial activities by different workers should be more powerful to tightly pack the system and will run the system more fancifully. As a whole support should be generated for the moral and spiritual development of the environment will be more meaningful here to run the functions of ecosystem more and more healthy and monitoring will be very much simple than complicated. One can easily access the system that the growth and development of the ecosystems become healthy. At the end of the monitoring restoration probably be meaningless because there will be no way to access the system because all will run smoothly and no conflict will be there due to excess amount of nutrients all the cyclic bio-geochemical cycles run continuously to flow the overall energy cycle a great in number and diversity of resource will normally develop better environment there. All are aware that restoration is the process of rebuilding a degraded ecosystem or disturbed ecosystem until it reaches its original state. Because, it is a stable state before going to any major disturbance or abnormality lead to forecast the prediction or judgment to work there. It broadcasts peculiarity of interconnection of flow of energy in any direction at anywhere within the system either confined or free from any complexity. This includes its pre-disturbance structure along with abnormal functions and composition there. It also states that the structure always associated with its taxonomic composition including complexity and tightness. Not only the above statement it also includes its function primarily or secondarily including primary productivity followed by secondary productivity of the ecosystem including majority of the cyclic patterns of nutrients to reach at the ultimate goal. As the system is out of work so the other type of scientific restoration is meaningless there, because no system will run smoothly due to nonfunctioning of the factors in natural forests, degraded land as well as in plantation stand even in the agricultural field in the said area.

A strict restoration aims at attaining the "Pristine" state of the ecosystem truly. Thus, it has its sphere with global goals indicating the energy flow, nutrient cycling, dynamics of state and interaction of biota and a biota fruitfully there to earn good growth and health of the ecosystem in the healthy environment. So, its critical point is constant be predicted or functional.

The endpoint of the restored ecological state therefore should be valuable. It should be exact replicas of the pristine state not forcefully mitigate the end point of the productivity. Therefore, strict restoration has been criticized in the past and significantly moral to earn the goal of the ecosystem dynamics with the varied diversity with varied functions both in rhizosphere and in lithosphere. Thus, the restoration of strict type used broadly for aiming at an almost impossible endpoint after the study of long time span in the said area with different parameters which run the system normal and the ecosystem should be normal. Similarly, active restoration involves continuous human interactions to keep the succession, to be more judgmental and going towards the ecosystem climax type rather than flexible. No such categorical differential directly fluctuate after the huge perturbations in the ecosystem by continuous intervention of driving force. Therefore, it is always on the way towards preferred trajectory and run smoothly toward the endpoint and always draws the attention that is an exact replica of the pristine state to become more stable ecosystem in the forest ecosystem, degraded or plantation stand including agricultural sites with different means.

On the other hand, the liberal or passive restoration, does not necessarily consider the ecosystem vulnerable. It always signifies pre-disturbance state of the ecosystem as the ultimate goal. Instead, this approach 
traces the succession trend and analyses the composition along the fluctuations to flow the energy with the repeated flow of nutrients in the same territory. So, the system allows succession to follow its own trajectory, to develop the demand based ecosystem functioning and trend is always negative. The opposite trend is positive where costiveness of cyclic flow of nutrients takes place. That does not fully support the concept of dynamics without active interference of factors. This approach therefore, lacks energy flow and passive flow of nutrient structure which considers several different endpoints of the final ecosystem and the ecosystem becomes less functional due to competitiveness of the resources by positive and negative activators there.

Proper land management along with proper vegetation structure can counteract land degradation at Nayagaram site. Appropriate land management, including restoration, is essential to halt land degradation in natural forests, degraded forests, plantation stands and in agricultural fields of the Subarnarekha Basin in Nayagram of Paschim Medinipuir. Models dealing with this land management and vegetation mapping are therefore essential to keep the environment healthy and will make the ecosystem good. Therefore, public ownership of land has discouraged in the vicinity or nearby the forest and good management of the forest protection committees should be encouraged. From there, people will take advantage and community concept will develop which lead to develop forests, develop vegetation at degraded sites, and in the fringe of forests, and will encourage the people to save the forests and wild life as a whole to make the ecosystem empiric there. Gradually the system will automatically generate, settle the biomass there and postponed the degradation of land or soil. Management has its direct action to prevent serious land degradation in any area. It is applicable in Nayagram area also where serious problems like degradation of forests and land take place. A well-known model describing the phenomenon, called the "tragedy of the commons", was introduced by Garrett Hardin in 1968. The model is based on an actual situation where farmers had access to common land where they could graze their livestock without any restriction. It showed that, each person would only act in their own best interest with regard to access to natural resources. Such, behavior, in turns, lead to an escalation in land degradation. Data on vegetation characters showed significant value regarding the good health of Ecosystem at Kaluasarh in Nayagaram rather than other sites of the same block (Table 1). Here, highest number of species is found even the diversity index is highest (0.84) compared it with other 4 sites. It shows species richness also i.e. 1 compared with other study sites. It may be stated that the management of the forest is good due to active participation of forest protection committees (FPCs). Another point is that scared groves and related activities protect vegetation as a whole good and support the growth of the propagules and advent growth forms in the same forest. Not only that, here coppice work of sal forest is in scientific way which may develop shoots in a proper way. Collection of NTFPs and other products is in managerial ways which actively run to smooth function of the ecosystem to protect the entire environment also. Here, forest fire and illegal operations are controlled way which may be another factor that govern the good growth and luxuriant development of vegetation for near future. As a whole, Kaluasarh of Nayagram forest Range may be a role model to study and develop indices to justify the statement 'Healthy ecosystem for Healthy Environment'.

Table 1 Synthetic characters of Ecosystem Health to study the vegetation parameters at NAYAGRAM BLOCK, Paschim Medinipur, West Bengal, India.

\begin{tabular}{|l|c|c|c|c|c|}
\hline \multirow{2}{*}{$\begin{array}{c}\text { No. of Spp./ Indices } \\
\text { for Eco-Health }\end{array}$} & \multicolumn{5}{|c|}{ Study site for Ecosystem Health and Values (Ecosystem/Environmental) } \\
\cline { 2 - 6 } & Nayagram & Kaluasarh & Kurchibani & Malam & Kharikamathani \\
\cline { 2 - 6 } & $(1)$ & $(2)$ & $(3)$ & $(4)$ & $(5)$ \\
\hline Tree Species & 38 & 42 & 36 & 12 & 31 \\
\hline Shrubs & 22 & 27 & 17 & 41 & 23 \\
\hline Herbs & 82 & 78 & 43 & 86 & 34 \\
\hline Total spp. & 142 & 147 & 96 & 0.76 & 88 \\
\hline Diversity & 0.80 & 0.84 & 0.79 & 0.60 & 0.82 \\
\hline Dominance & 0.60 & 0.70 & 0.50 & 0.70 & 0.70 \\
\hline Evenness & 1.00 & 0.90 & 0.80 & 0.80 & 0.80 \\
\hline Species Richness & 0.90 & 1.00 & 0.89 & 0.6 & 0.7 \\
\hline TEV & 0.9 & 1.0 & 0.7 & 0.7 & 0.8 \\
\hline TEnV & 0.7 & 1.0 & 0.7 & & \\
\hline
\end{tabular}

N.B.: Scale for TEV and TEnV has been arranged from 0.1 to 1 to establish the actual health character, here Kaluasarh is showing highest scale value may be due to less threat by exotic intervention, though statistical analysis is required to establish the actual clarification which need more sampling rather than 4 study sites (Kurchibani and Malam may be regarded as only one site). 
V. Photographic Plates (Plate 1 to 6 )

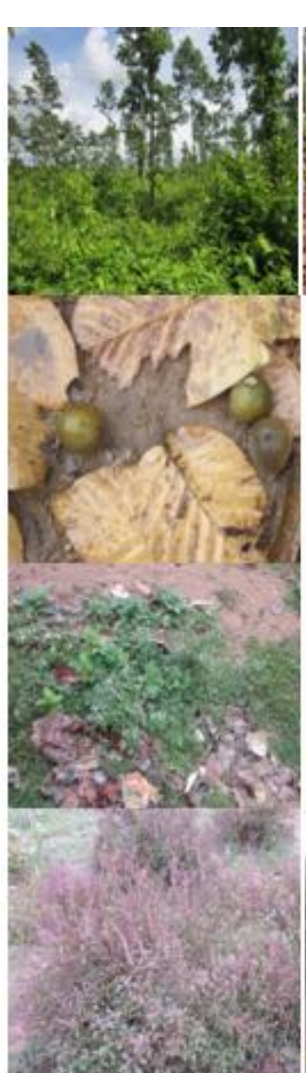
Photo Plate-1

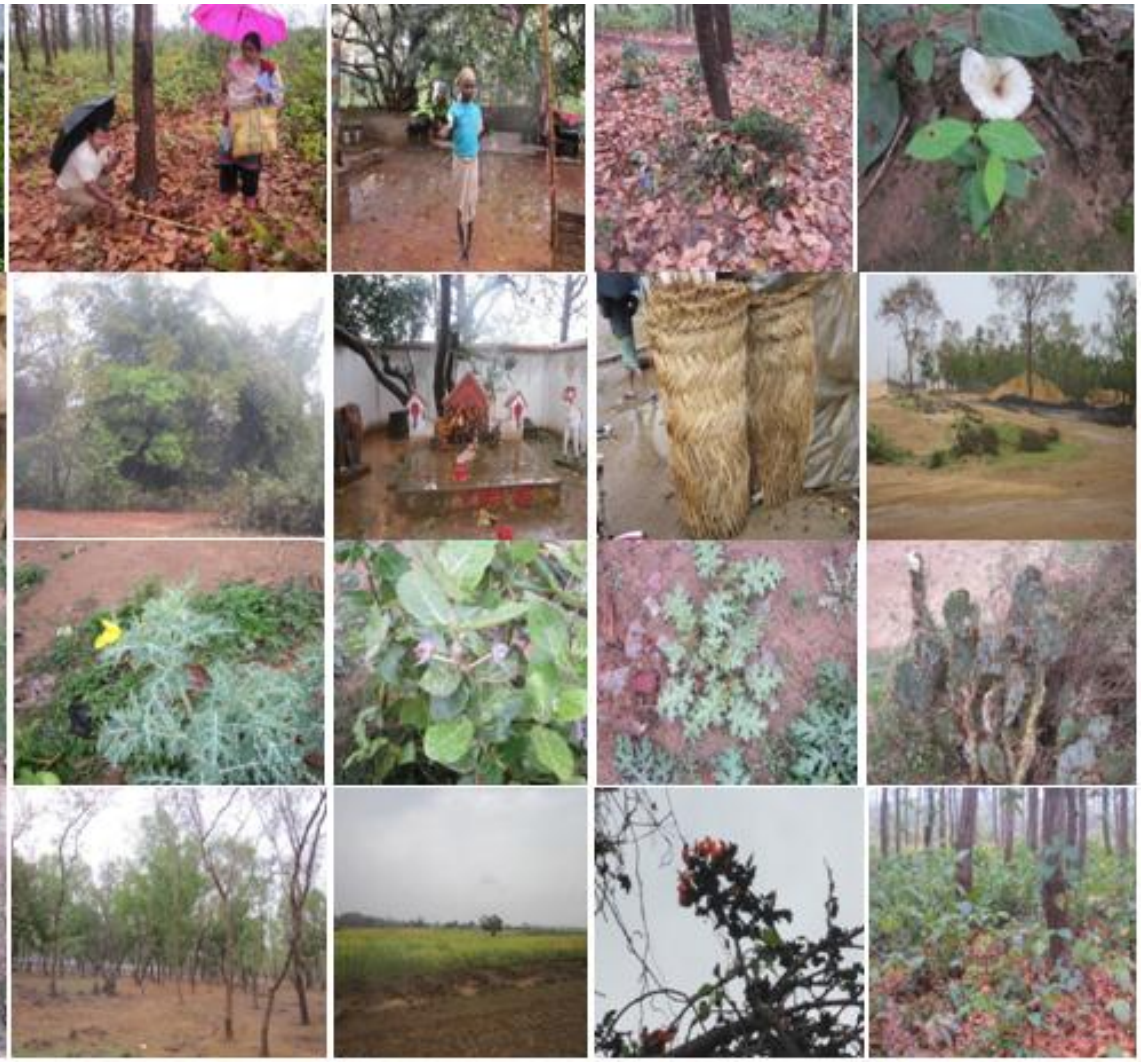

Figures: 1-20 (Upper Left to Right and followed by lower left to Right), Legend: 1-Dense Natural Sal (Shorea robusta) forest during post monsoon; 2-Author watching litter fall pattern of vegetation where forest staff of Nayagram Range measuring the thickness of litter deposition; 3-Same forest during winter after 6 months interval at Kaluasarh, Nayagram, PaschimMedinipur; A tribal of nearby village is standing in front of Sacred grove Kaluasarh along with tree 'Bis gab' (Diospyros sylvatica); 4-Vanda tesselata-An epiphytic orchid falling on a ground due to destruction of host tree is a serious degradation of species from forest which need immediate rescue; 5-Wild mushroom blooming on forest floor along with herbs; 6-Bahera fruits (Terminalia bellerica) along with dry sal leaves; 7-Bamboo vegetation near forest and margin of village; 8-Ma-Sataiburi sacred grove conserving species like Gelonium multiflorum and Anthocephalus cadamba; 9-Mat of Saccharumsp. is used to prepare hut near Subarnarekha river which is economically and environmentally also eco-friendly; 10-Large Sissoo (Dalbergia sissoo) plantation near river Subarnarekha of Nayagram, Paschim Medinipur, West Bengal, India; 11-Leucas linifolia near river bank in blooming stage; 12-Blooming plant 'Seal kanta' (Argemone maxicana) near river bank;13-Calotropis procera on sandy river bed; 14-Solanum sisymbrifolium during growing stage, 15-Community of Opuntia dillenii; 16-Ocimum sanctum; 17 Degraded plantation stand; 18-Cultivation of Brassica sp.; 19-Palas (Butea monosperma); 20-Ground shrubs in sal forest dominated byClerodendum indicumso called Ghentu. 


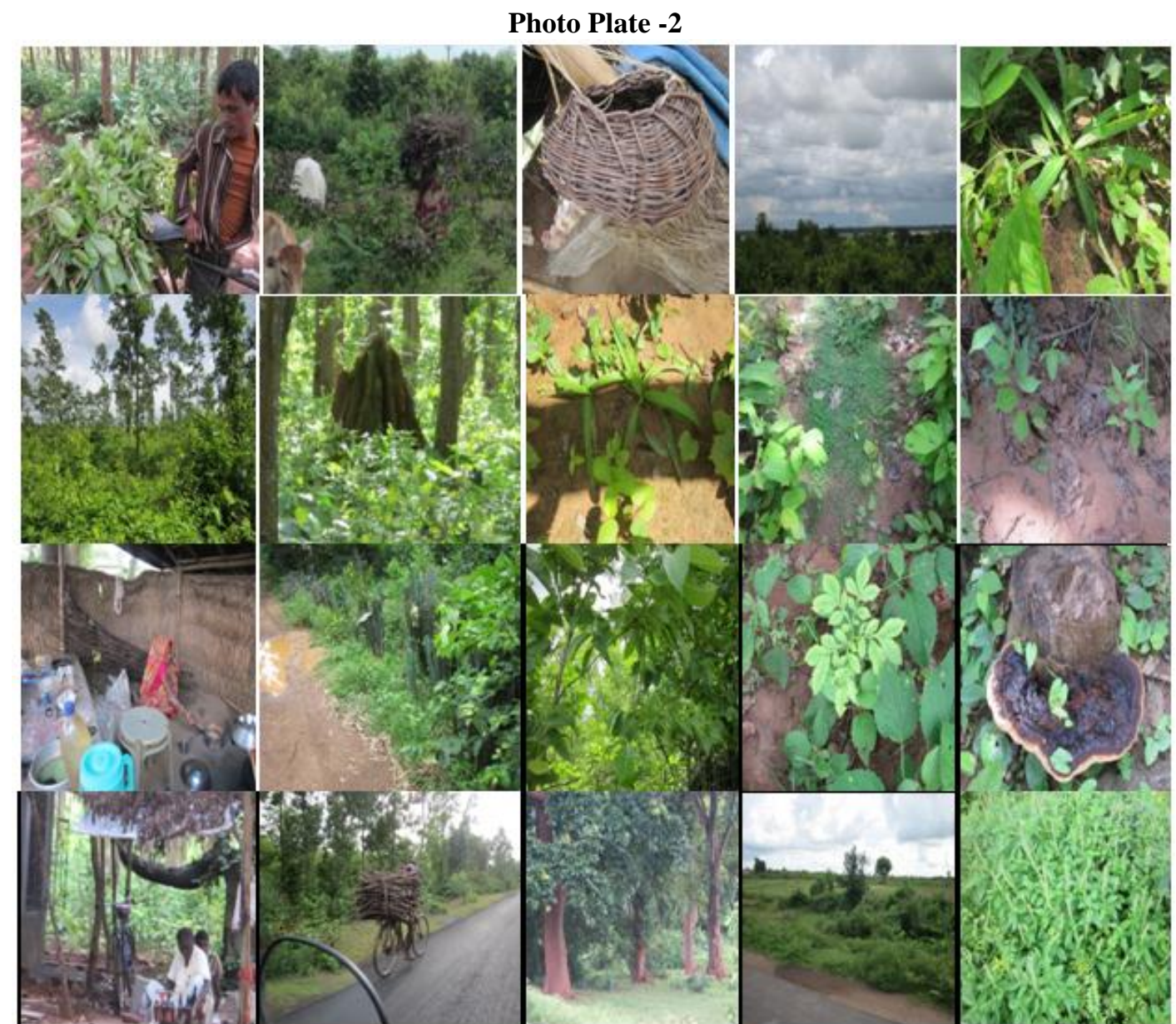

Figures: 21-40 (Upper Left to Right and followed by lower left to Right), Legend: 21-People collecting twigs of Glochidion lanceolariumfor cattle feed; 22-Woman collecting fuel wood from forest; 23-Cotainer of fisher man made by Ichnocarpus frutescens stem (woody climber of forest); 24-Sal vegetation along the river bank near Kurchiboni village; 25-Safed musli in wild condition (Chlorophytum tuberosum); 26-Sal vegetation of coppice type (Coppiced during 2012, 2013), some mother plants are left untouched for producing propagule (Seeds) though they are largely coppice type; 27-Ant hill having ants causing litter decomposition during monsoon, 28-Plants of Curculigo orchioides -A most promising medicinal plant of the forest community; 29Ground cover dominated by small herb like Desmodium triflorum; 30-Young plants of Aristolochia indica ; 31-Local women using fuel of dry sal twigs collected from forest; 32-Cereus hexagonus in living fence; 33 Kurchi (Holarrhena pubescens); 34-Wild Arum-(Amorphophalus sylvatica); 35-Sal stump attacked by fungus (Polyporus shorae); 36-People consuming local wine made up of Mahul flowers in open place (Produced from Flowers of Madhuca indica); 37-People carrying wood for their fuel purpose; 38-Old sal trees reserved for seed production; 39-Degraded stand filled with Lantana camaraand Eupatorium odoratum (Exotic species); 40-Wild roadside basil (Ocimum basilicum) dominated community along with co-dominant Ban-nil (Tephrosia purpurea) having potential to study VA-Mycorrhizal status in the lateritic forest area of West Bengal, India. 

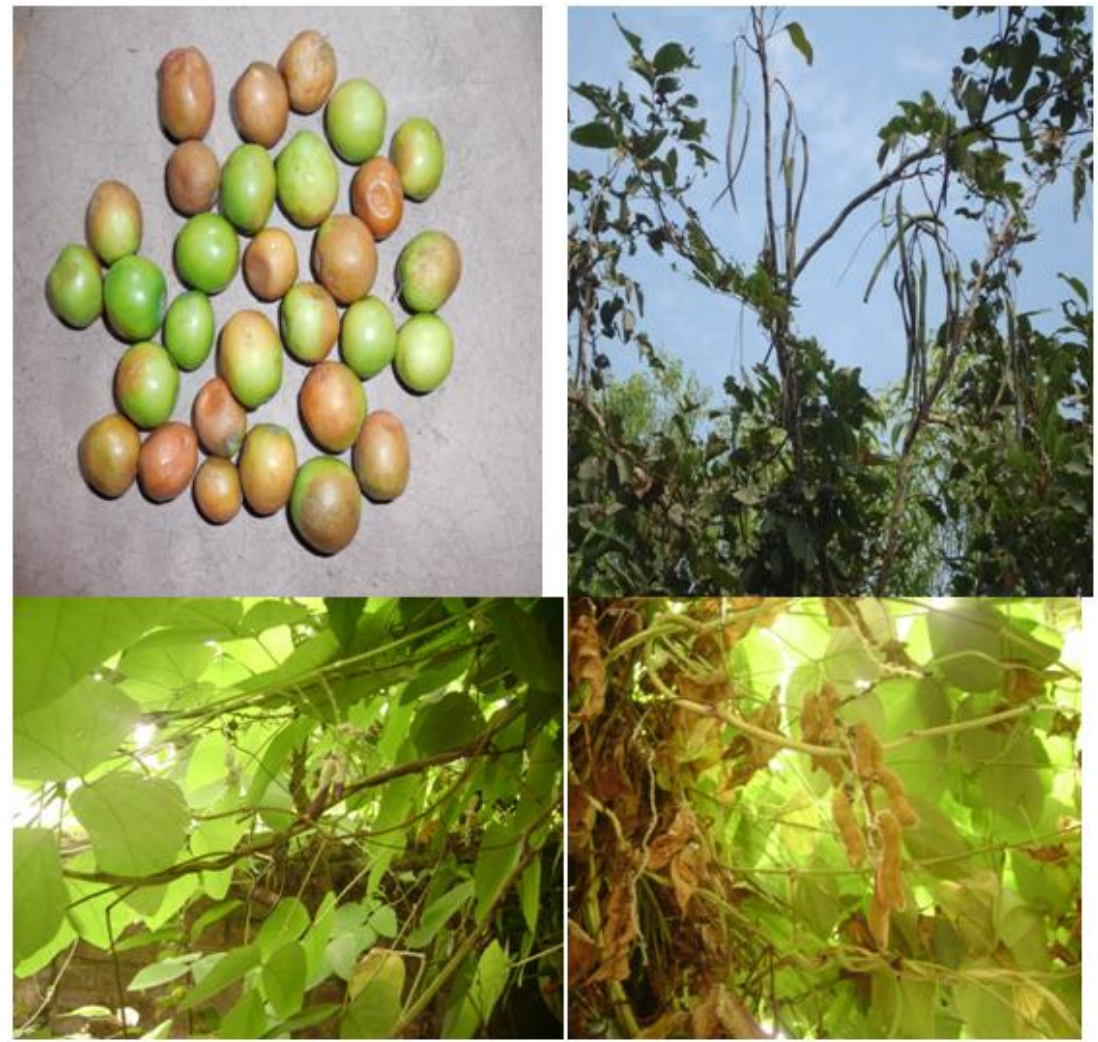

Figures: 41-44 (Upper Left to Right and followed by lower left to Right), Legend: Zizyphus jujuba, Cassia fistula, Mukuna pruriens (Flowering stage and Fruiting stage), the plants going to vanish day by day due to illegal operations knowingly or unknowingly in the forests of Nayagram where it was found common 10 years back from the present study. Note that now the same species is found common in hills of Panchet, Purulia, West Bengal, India. Seeds of the species like Mukuna is broadly used in laboratory to treat the Parkinson Disease.

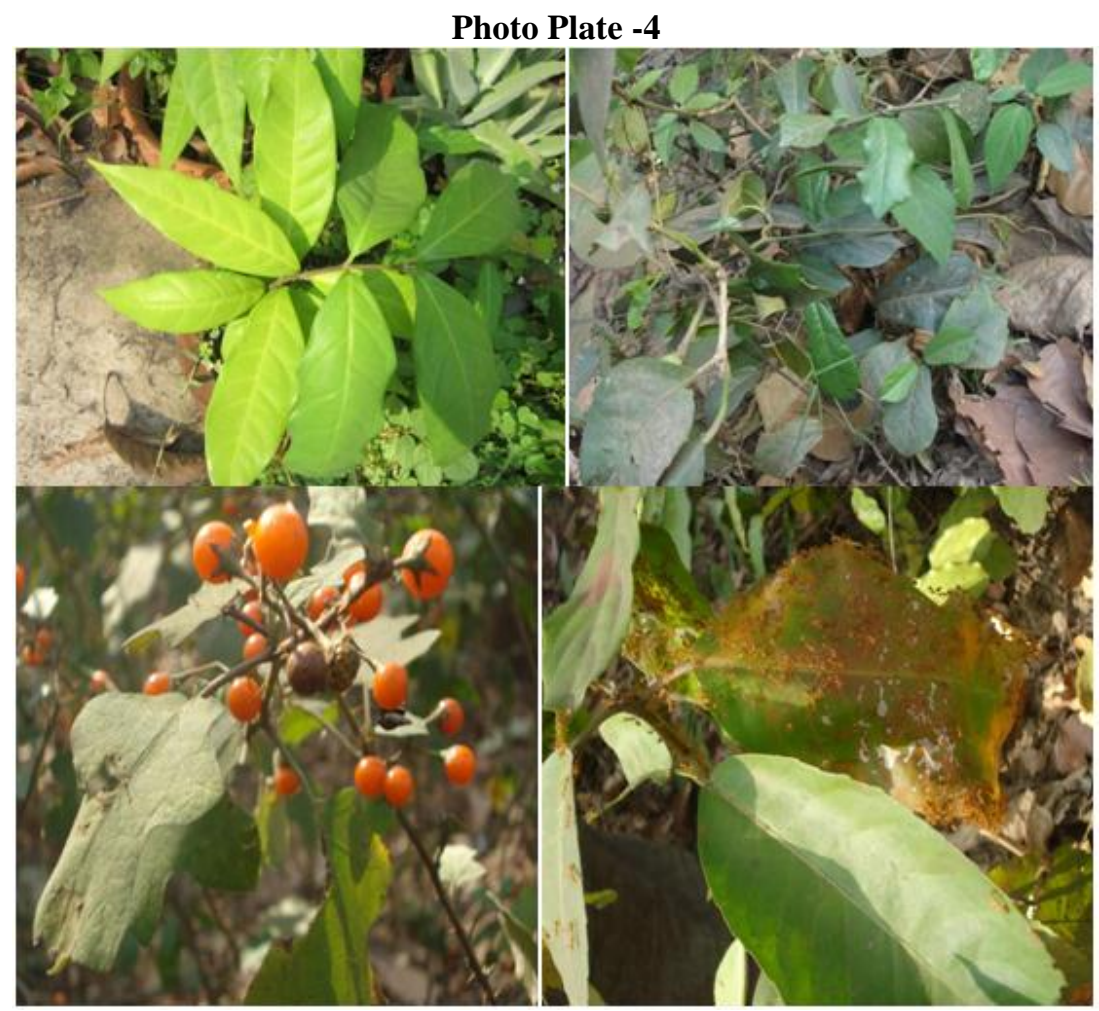

Figures 45-48: Lagerstroemia indica plant growing in an earthen pot to study the ecological behavior in insitu habitat, under varied microclimate at protected gardens, Paschim Medinipur, West Bengal, India., 
Aristolochia indica - The most promising interesting medicinal plants of lateritic southwest Bengal, facing serious threat day by day due to havoc collection by outsiders as this having good market demand. Fruits of Solanum trilobatum (Solanaceae) at the lower left and at the right putla plant (Croton oblongifolius) infested by red ants, the eggs are important Non Timber Forest Produce (NTFP/NWFP) and marketed in local hat (Weekly market), the local people used the same to stop hooping cough even to protect common cough is a source of organic acid.

\section{Photo Plate -5}



Figures 49 -54 : Bamboo thicket conserving birds, Gymnema sylvestris of Asclepiadaceae -an ant diabetic plant, Plant of Madhuca indica of Sapotaceae on earthen pot, Medicinal plant Gloriosa superba of Liliaceae, Curculigo orchioides (Talamuli-a medicinal plant), Dioscorea bulbifera of Dioscoreaceae (Medicinal Plant).

\section{Photo Plate -6}




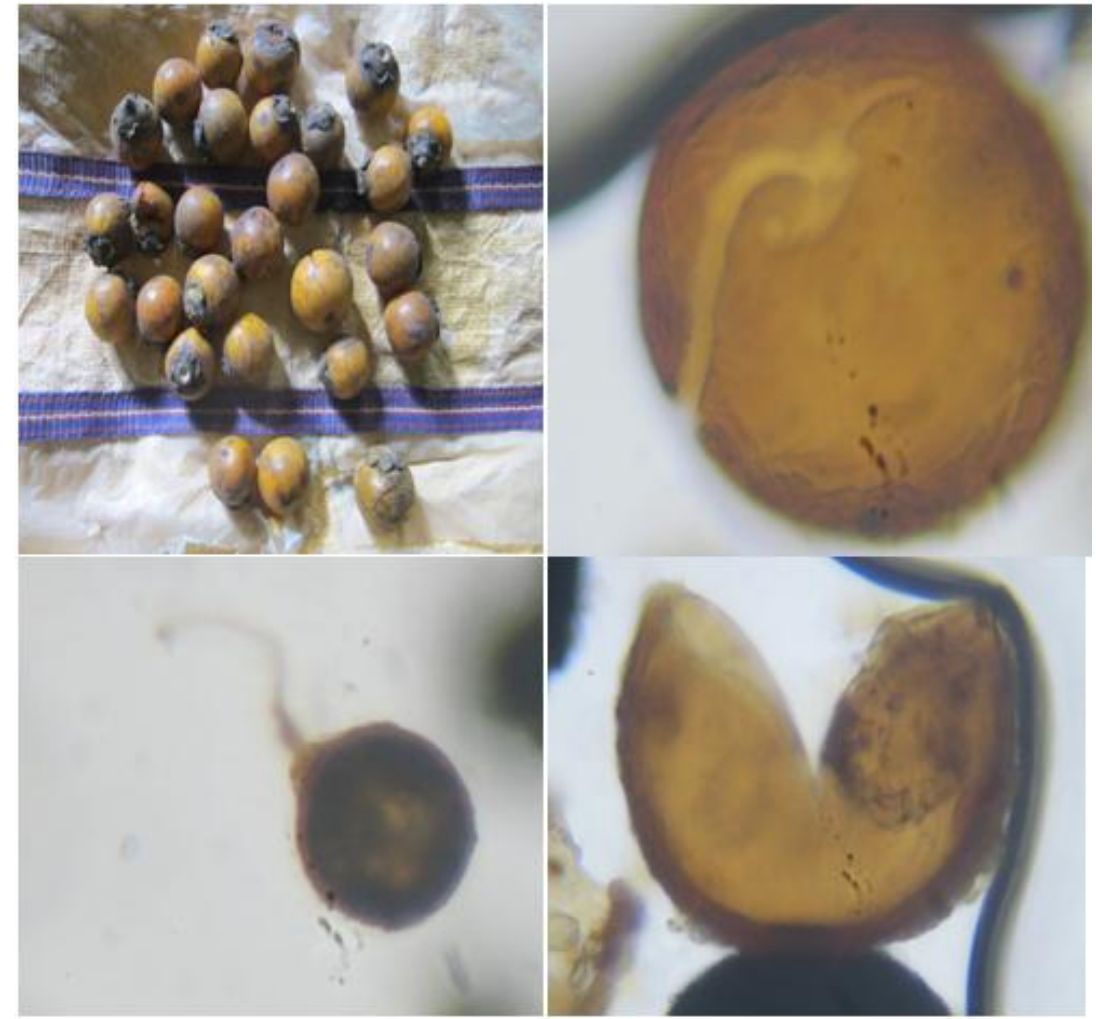

Figures 55-58 : Upper left is Ripe Fruits of Diospyros tomentosa so called Kend, or Kendu (Santhals), as edible fruits, Upper right and lower two photographs are Vesicular Arbuscular Mycorrhizal (VAM) spores isolated from soil of Nayagram, Paschim Medinipur, West Bengal, may be used largely as bio-fertilizer in near future to develop the economy of local people and to restore the ecosystem in some extent to eliminate chemical fertilizers used there in a huge amount.

\section{Summary And Conclusion}

Nayagram can follow the said model because; it has its main pressure due to excessive grazing and browsing, by quadrupeds. Round the year, cattle move here and there and cause serious threat on vegetation and on land. Another cause is illegal felling, chopping, litter collection, fuel collection, green leaf collection, collection of roots, rhizomes, corms, medicinal plants, pant parts of commercial importance knowingly or unknowingly which is increasing day by day. This must be the main cause so called over collection or excessive collection without any proper management. The collectors are always busy to earn more biomass of commercial kind without any management except only one site. So, major parts could not follow scientific management or indigenous management except the above mentioned site (Graph 1,2,3).

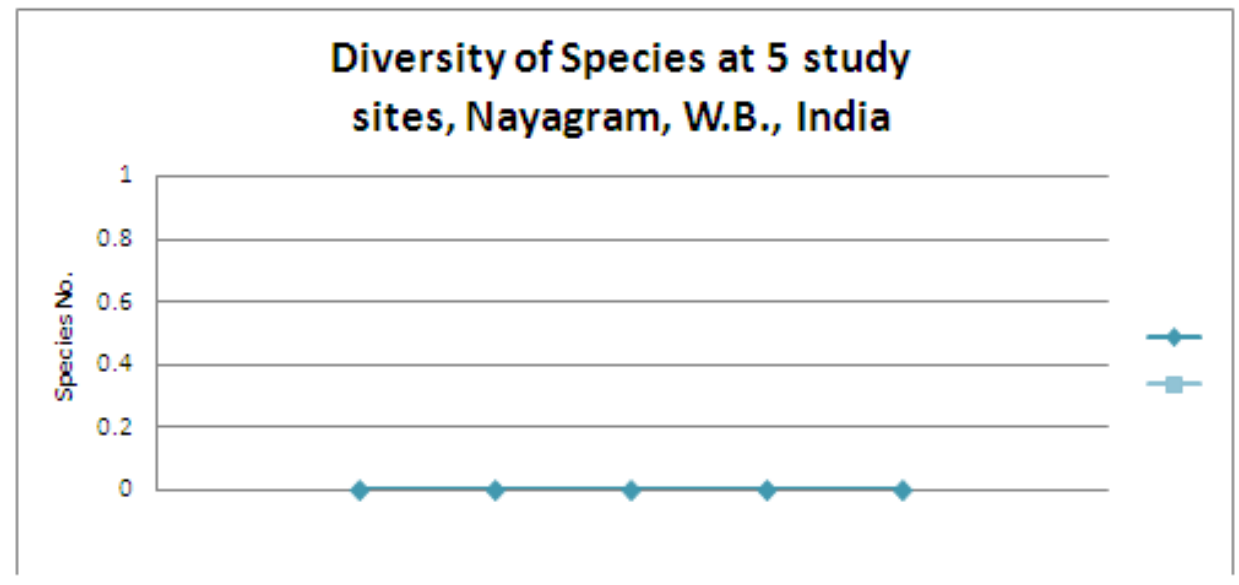

Graph 1. Number based Species diversity at 5 study sites of Nayagram, Paschim Medinipur, W.B. , Note that X axis represents study sites, namely Nayagram, Kaluasarh, Kurchibani, Malam and Kharikamathani. 

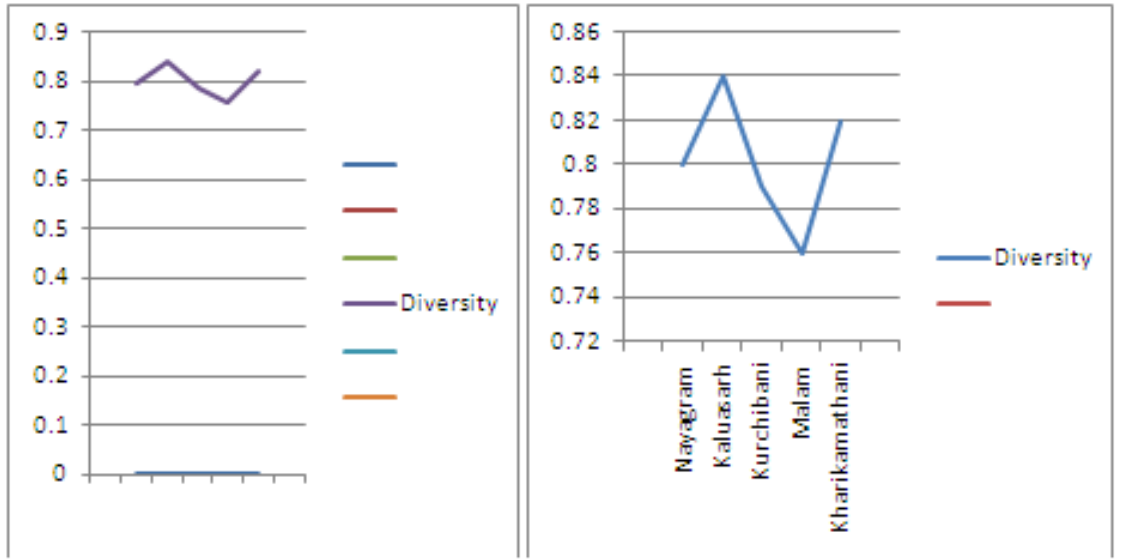

Graph 2.Species Richness at 5 study sites of Nayagram, based on species richness value (left); Graph 3.Indicates Diversity indices of species based on Diversity indices at 5 sites of Nayagram, Paschim Medinipur (at right).

Therefore, a guideline should be prepared and should be required to follow the collection pattern as well as pattern of management to get more growth to develop more biomass. Therefore, modeling is required and the model may be the natural resource model to justify the problem there by. This model may be extended to apply to any situation where commonly held natural resources may be used by many people without any individual responsibility and without any critical situation. Such situations lead to increasing pressure on finite natural resource as the human population increases exponentially over the globe. If property rights and resource management are not satisfactory to rule the ecosystem dynamics, the governing force has to be predicted and needed more attention to sustain the resource there to safeguard the vegetation and land to mitigate the problem in a more stress-less condition. Our responsibilities are not clearly outlined anywhere to sustain the ecosystem and also to safeguard or the use of natural resources, an inevitable over exploitation. The dystrophy as a whole is that it is predicted to earn the goal over the area to pose the system functions over the controversial term dysfunction of these systems which lead to follow the pattern of ruined ecosystem. Remember that in near future scientists and students along with researchers generate actual bio-ecological model to manage the dwindling ecosystem as a whole. Not only that its expanded application could continue the path of activity there to develop a green globe and unturned earth with unbelievable green crop very soon. What and when they provide, ultimately, was a link among social, political, local, natural, artificial as well as biological sciences into one framework as integrated one to illustrate how they relate to the management of natural resources and their flow to all to develop a good path for healthy ecosystem for healthy environment.

\section{Acknowledgements}

The authors express their sincere thanks to the people of Nayagram, Kharikamathani, Malam, Kurchibani, Kaluasarh, Kalmapukuria villages of Paschim Medinipur District, West Bengal for their endless help during field investigations. Office staffs of different Government and semi /quasi Govt. offices are highly acknowledged. We, thank much more to our College Principals, for their kind help including librarians during consultation of literature. Librarian, Jhargram Raj College, Jhargram, Paschim Medinipur, West Bengal is well acknowledged. Head of the Present Department, Darjeeling, some friends of CNH, BSI, Kolkata are well acknowledged. We convey thanks to Sri Amalesh Jana, Environmentalist, Plant Grower cum horticulturist, Panskura, PurbaMedinipur. We acknowledged our daughter Atmaja Avirupa Das, a student of Class-I, who helped us much during field visit. Special thanks convey to Range officer, Nayagram and forest guards for assistance during vegetation study in field. Sri. Ashoke Kumar Sen, Present Range Officer; Sri Manoj Kumar Mojumder, Beat Officer, Nayagram, Paschim Medinipur, West Bengal are highly acknowledged.

\section{Journal Articles:}

\section{References}

[1]. Das, D. Community study of plant species in coastal areas of Mohana and Old Digha of PurbaMedinipur District with special reference to Eco-sustenance of life in near future, Indian J. App. \& Pure Biol., Vol.-29 (2), 2014, In Press (for July Pub.)

[2]. Bertini, A. and Maritinetto, E. Reconstruction of Vegetation transects for the Messinian-Placenzian of Italy by means of Comparative analysis of Pollen, leaf and Carpological records., Paleogeography, Paleoclimatology, Paleoecology, 304(2011), 2011, 230-246.

[3]. Bertini, A. and Maritinetto, E. Messinian to Zanclean Vegetation and Climate of Northern and Central Italy, BollettinodelaSocietaPaleoontologiaItaliana, 47(2), 2008, 105-121.

MacArthur, R.H. Pattern of Species Diversity, Biol. Rev., 40, 1985, 510-533 
[4]. Arrow, K. J. and Fischer, A. C. Environmental Preservation, uncertainty and irreversibility, Quart. J. Econ., 88, 1974, 312-319.

[5]. Sarkhel, S. Ethnobotanical Studies of Folklore plants used in treatment of Snakebite in Paschim Medinipur District, West Bengal., Asia Pac. J. Trop. Biomedicine, 4(5), 2014, 16-420.

[6]. Ghosh, P. Preliminary studies on Ethno-botanically important Non Timber Forest Produces (NTFPs) in Jamboni Block of Paschim Medinipur District of West Bengal, IOSR-Journal of Pharmacy and Biological Sciences, 9(5), 2014, 59-66.

[7]. Das, D. and M. Das. Vegetation Ecology of Coastal belt of Khejuri area of Purba Medinipur District with special reference to Hijli Coast, West Bengal, India, IOSR-Jour of Pharmacy, 4(2), 2014, 2319-4219.

[8]. Ghosh, P. and D. Das. Some medicinal Plants of Joypore forest Range of Bankura, West Bengal, India, Environment \& Ecology, Kalyani, Nadia, W.B, 32(2), 2014, 465-470.

[9]. Das, D. An Ecological Journey to Pandam through Mulgaon Areas of Darjeeling Himalaya with special reference to Monitoring of Vegetation in West Bengal, India, IOSR-PHR, 4(4), 2014b, 53-79, DOI: 10.9790/3013-040453-79, ANED:DOI:05.3013/044053079

[10]. Whittaker, R.H. 1972. Evoloution and measurement of species diversity, Taxon, 21,1972, 213-251.

[11]. Oostings, H.J and WD Billings. 1942. Factors affecting vegetational zonation on coastal dunes.,Ecology 23, 1942, $131-142$.

[12]. Simpson, E. H. Measurement of Diversity, Nature, 163, 1949, pp. 688.

[13]. Pielou, E. C. Species Diversity and pattern diversity of in the study of Ecological; Succession, Jour. of theoretical Biology, 10, $1966,370-383$

[14]. Sorensen, T. A method of establishing grops of equal amplitude in plant sociology based on similarity of species and its application to analyses of the vegetation on Danish commons, KongeligeDanskeVidenskabemesSelskab, 5(4), 1948, 1-34.

[15]. Bray, J.R. and Curtis, J.T. 1957. An Ordination of the upland forest communities of Southern Wisconsin., Ecological Monograph, 27: 325-349.

[16]. Morisita, M. Measuring of interspecific association and similarity between communities, MemFracSci Kyushu Uni, Ser E Bio., 3,1959, 65-80.

[17]. Dice, Lee R. Measures of the amount of Ecologic Association between species, Ecology, 26(3),1945, 297-302, Doi: 102307/1932409, JSTOR 1932409.

[18]. Wolda, H. Similarity Indices, sample size and diversity, Oecologia (Berl.), 50, 1981, 296-302.

\section{Books:}

[19]. Jorgensen, S. E; Xu, Fu-Liu. and Costanza, R. Hand Book of Ecological Indicators for Assessment of Ecosystem Health, Second Edition, CRC Press, New-York, 2010, pp.-484

[20]. Dennis, J.G. and Ruggiero, M.A. Biodiversity Inventory: Building and Inventory at scale from local to global. In: Szaro, R.C. and Johnston, D.W. (Eds.). Biodiversity in Managed Landscapes., Oxford Univ. Press, Oxford, 1996, pp. 149-156.

[21]. Solbrig, O.T.(Ed.). From genes to ecosystems: A Research Agenda for Biodiversity, IUBS, Paris, 1991.

[22]. Norton, B.G. Why Preserve Natural Variety? Princeton University Press., Princeton, 1987

[23]. UNEP. Global Biodiversity Assessment, Cambridge University Press, Cambridge, 1995.

[24]. Mac Arthur, J. The Economic Valuation of Biodiversity, Its implications and importance in Bio resource planning, and initiations for its regular use in planning conservation projects in India. In: Pushpagadan, P., Ravi, K. and Santosh, V.(Eds.). Conservation and Economic Evaluation of Biodiversity, Vol. 2, Oxford \& IBH Publ. Co. Pvt. Ltd., New Delhi, 1997, pp. 510-533.

[25]. Greipsson, S. Restoration Ecology, Jones \& Bartlett Learning, USA, 2011, pp-387.

[26]. Dash, M. C. and Dash, S. P. Fundamentals of Ecology, Third Edition, The McGrewHill Companies, Tata McGrew-Hill Education Private Limited, New Delhi.,2010, pp.1-562.

[27]. Prain, D. Bengal Plants, Vol.-I, (Revised Edn, 1903 ), 1963, BSI, Calcutta.

[28]. Prain, D. Bengal Plants, Vol.-II, (Revised Edn, 1903), 1963, BSI, Calcutta.

[29]. Haines, H. H. The Botany of Bihar and Orissa, Vol. I-IV, (1921-1925), BSI, Calcutta.

[30]. Hooker, J. D. Flora of British India, Vol. 1-VII, (1892-1897), BSI, Calcutta.

[31]. Anonymous. Medicinal Plant Resources of South West Bengal, Vol.-I, 2005, Research Wing, Directorate of Forests, Govt. of West Bengal.

[32]. Anonymous. Medicinal Plant Resources of South West Bengal, Vol.-II, 2010, Research Wing, Directorate of Forests, Govt. of West Bengal.

[33]. Anonymous. Flora of West Bengal, Vol.-I, BSI, Kolkata, Flora of India, 1997, Series-2

[34]. Groom, M. J; Meffe, G. K ; Carroll, C. R. and Contributors. Principles of Conservation Biology, Third Edition, Sinauer Associates, Inc. Publishers, USA.,2006, pp.-793.

[35]. Rao, R. R. and Sharma, B. D. A Manual for Herbarium Collections, BSI, Brabourne Road, Kolkata-1., 1990.

[36]. Oostings, H. J. The structure of plant communities, WH Freeman Company., San Francisco, California, USA, 1956, pp.32-51.

[37]. Muller-Dombois, D. and Ellenberg, H. Aims and methods of Vegetation Ecology, NY: Wiley and Sons, 1974.

[38]. Mabberley, D. J. A Portable dictionary of the Vascular Plants, Cambridge University Press, 1997.

[39]. Bennet, S. S. R. Name Changes in flowering plants of India and adjacent regions, Triseas Publishers, Dehra Dun, India, 1987.

[40]. Curtis, J.T. The Vegetation of Wisconsin, University of Wisconsin Press, Madison, WI, 1959, pp. 657.

[41]. Shannon, C.E and Wiener, W. The mathematical theory of Community, University Illinois Press, Urban, 1963.

[42]. Margalef, R. Perspective in Ecological theory, University of Chicago Press, 1958.

[43]. Muller-Dombois and Ellinburgh, H. Aims and methods of Vegetation Ecology, John Willey \& Sons Inc., New York, 1974.

\section{Thesis:}

[44]. Das, D. Study of Vegetation Ecology of Forests of lateritic SouthWest Bengal with special reference to Non-Timber Forest Produce (NTFP) Productivity, Ph. D Thesis awarded from Vidyasagar University, West Bengal (Work From CNH, Botanical Survey of India, Shibpore, Howrah, West Bengal), 2007.

\section{Other Articles:}

[45]. www: Chanda, S. Man-Elephant Conflict in South West Bengal, A-web Article.,pp, 1-15

[46]. Anonymous. "Contact details of Block Development Officers". Paschim Medinipur District. West Bengal Government., Retrieved 2011-04-10, 2011.

[47]. Stohlgren, T.J. and Quin, J.F. Status of National Resources Data Bases in National Parks: Western Region., National Park Service, Co-Operative Park Studies Unit, Technical Report 44., University California, Davis, CA,1991.

[48]. Garrett Hardin. The Tragedy of the Commons, "The population Problem has no technical solution it requires a fundamental extension in morality" American Association for the Advancement of Science, New Series, 1968, Vol. 162, No. 3859: 1243-1248, $13^{\text {th }}$ December. 